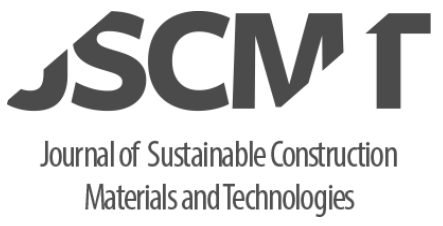

J Sustain. Construct. Mater. Technol. 4(1) (2019) 318-322
Journal of Sustainable

Construction Materials

and Technologies

www.eds.yildiz.edu.tr/jscmt

\title{
The Essentials of Sustainable Building Construction Practices
}

\author{
Dr.C.Balaji venkateswaran ${ }^{a}{ }^{*}$ ME (Struct.) Ph.D \\ a Anna University, Chennai 600025, Tamil Nadu, India
}

Manuscript Received January 12, 2019; Accepted February 21, 2019

\begin{abstract}
The sustainable building practices are essential techniques considered in construction of buildings in order that the resources of the earth are not depleted and the resources are carried forward to the future generations. This paper discusses the essentials of sustainable building construction practices in India. The techniques through which the sustainability could be achieved i.e., alternate building technologies available for adoption, building materials suitable to achieve sustainability and renewable energy sources etc., are discussed.
\end{abstract}

Key words: Sustainable buildings; Energy; Materials; Renewable energy

\section{Introduction}

Sustainable development is defined as any development planned to provide livelihood to humans, which keeps eye on the needs of the future generation by the way of minimum use of natural resources and prevention of depletion of environment and natural resources by adopting suitable building technologies and practices.

Buildings which are constructed today for various uses consume energy and natural resources which are detrimental to the environment. It is estimated that buildings consume about $25 \%$ of the energy produced in India [1]. According to world watch institute about $40 \%$ of the total energy use is dedicated to the construction and maintenance of buildings [1].

According to a study [1], buildings which includes residential, commercial and residential buildings, globally consume around $31 \%$ of the global energy production and emitted 1900 megaton of carbon. It is estimated that by 2050 , energy consumption by buildings sector will rise to $38 \%$, emitting 3800 megaton of carbon in to atmosphere. Thus, it is imperative to practice sustainability in every sphere of building construction.

\section{Sustainable building practices}

The sustainable building practices include the following

- Energy conservation

- Use of environmentally friendly materials.

- Maximising the use of locally available materials and their uses.

- Recycling of building wastes.

- Use of renewable energy sources.

- Use of industrial wastes and mine wastes

- Adoption of energy efficient building techniques.

*Corresponding author. +919486277496

E-mail address:bakrkaku@gmail.com

https://doi.org/10.29187/jscmt.2019.35 


\subsection{Energy conservation in buildings}

There are two types of energy in buildings 1.Embodied energy 2. Operational energy

\subsubsection{Embodied energy}

It is the energy required to manufacture a construction material and supply it to the point of use. Table 1.0 [2] shows the energy requirement of primary building materials. The energy consumed by various building materials on their production is listed. It could be observed from the table that the common building material in any building construction i.e. cement and steel are having high embodied energy requirement. Even though steel and aluminium are high energy intensive materials but they can be recycled cheaply in terms of energy.

Table 1. Materials and their energy requirement

\begin{tabular}{l|l|l}
\hline Primary requirement & Material & Primary energy requirement (Giga joules(GJ)/tonne) \\
\hline \multirow{2}{*}{ Very High Energy } & Aluminium & $200-250$ \\
& Stainless steel & $50-100$ \\
& Plastic & $100+$ \\
& Copper & $100+$ \\
& Steel & $30-60$ \\
High Energy & Lead & $25+$ \\
& Glass & $12-25$ \\
& Cement & $5-8$ \\
& Plasterboard & $8-10$ \\
Medium & Lime & $3-5$ \\
& Clay bricks \& tiles & $2-7$ \\
\hline
\end{tabular}

Embodied energy in a building result from the use of materials, techniques of building construction and the structural design we choose to construct a building. In order to achieve sustainability in construction, embodied energy in a building should be minimum. Various constructions techniques are available to achieve minimum embodied energy in a construction. The use of precast structural elements, use of Compressed Stabilised Earth Blocks (CSEB) in place of burnt clay bricks, as CSEB masonry utilises only $40-50 \%$ of energy as that of bunt clay bricks [2] lead to cost effective, energy conscious building technology. Embodied energy of Reinforced Cement Concrete (RCC) framed structure building is $30 \%$ higher than that of load bearing structure using burnt clay bricks [2]. A short span RCC frame reduces steel requirements in beams and columns. Alternative building technologies such as ferrocement channel roof, use of shell roofs, filler slab roof reduce the embodied energy by at least 30\%[2]. The table 2.0 [2] shows the energy consumption of alternate roof technologies in comparison to the conventional RCC solid slab roof.

Table 2. Energy in different roofs/floor system

\begin{tabular}{|c|c|c|c|}
\hline \multicolumn{4}{|c|}{ Energy in different roofs/floor system $($ span $=3.60 \mathrm{~m})$} \\
\hline Number & Type of roof/floor & $\begin{array}{l}\text { Energy/M } \mathrm{M}^{2} \text { of plan area } \\
\text { in Mega joules }(\mathrm{MJ})\end{array}$ & Equivalent of RC solid slab energy (\%) \\
\hline 1 & RC slab & 730 & 100 \\
\hline 2 & Stabilised Mud Block (SMB) filler slab roof & 590 & 80.78 \\
\hline 3 & $\mathrm{RC}$ ribbed slab roof & 491 & 67.30 \\
\hline 4 & Composite brick panel roof & 560 & 76.7 \\
\hline 5 & Burnt clay brick masonry vault roof & 575 & 78.8 \\
\hline 6 & SMB masonry vault roof & 418 & 57.30 \\
\hline 7 & Mangalore tile roof & 227 & 31.1 \\
\hline 8 & Ferroc concrete roof & 158 & 21.60 \\
\hline
\end{tabular}




\subsubsection{Operational energy}

Energy consumed during the life span of a building in its operation and maintenance, after its construction is called as the operational energy. Operational energy is spent in heating, cooling, lighting and the use of appliances in buildings. Current estimates put India's energy usage per $\mathrm{m}^{2}$ of building at 3-4 times more than reasonably efficient building practices in the world [2].

During the last decade, there has been an increase in $13 \%$ in the consumption of electricity in the Indian residential and commercial sector [2]. Heating Ventilation and Air Conditioning (HVAC) is the biggest contributor to operational energy in India.

Significant reduction in energy demand can be achieved if energy efficient glazing combined with best orientation for lighting and proper planning of opening areas for heat exchange, building insulation, the use of energy efficient appliances and the renewable energy solutions are adopted.

\subsection{Use of environmentally friendly materials}

Building construction requires many construction materials. The following environmentally friendly materials can also be used in sustainable building construction based on the functional requirement of a building.

\subsubsection{Bamboo}

Bamboo is an excellent construction material. It has many uses in the construction of a building, as it possesses many structural properties like high compressive strength, bending stiffness, lightweight etc., Bamboo is a grass type plant which is self renewable and is one of the fastest growing plants on earth.

\subsubsection{Cork}

Cork is the outer bark of an evergreen oak tree [3].The outer layer is regenerated by the tree and it is one of the renewable natural sources. It has many several useful properties which make it a popular construction material, chief among them are light weight, low density, impermeable, elastic, low conductivity, durable, fire resistant etc.,

\subsubsection{Rubber}

Rubber is a product from latex, a milky sap from rubber tree. Rubber possesses high elastic property, low conductivity, shock absorbent etc, and it is renewable, grown in evergreen tropical forest regions.

\subsubsection{Earth}

Earth has been in use as a building material since the advent of building technology. Earth has many uses in making a building sustainable i.e. they can used as building blocks , mortar, filling material etc.,. CSEB building blocks stabilised with cement(less than 5\%) can used as an alternative to high energy intensive burnt clay bricks. Earth is a locally available material and therefore it is also cost effective.

\subsubsection{Thatches}

Thatches are structural members made from coconut, palm leaves etc., .Thatches are used as structural material since time immemorial. Properties of thatches are many, they are weather resistant, natural insulator, relatively light, less timber and they are versatile roof material [4] [5]. Thatches are widely used as roofing material in tropical countries.

\subsubsection{Lime}

Lime is an excellent building material. It has been in use as construction materials for many centuries .They are primarily used as mortar for masonry construction and to colour the walls. They can be used as replacement for cement, as cement is a highly energy intensive material. 


\subsection{Maximising the use of locally available materials}

Locally available materials contribute a lot to sustainable building construction. The use of CSEB blocks, use of locally available stones for masonry, use of locally available earth for filling and for masonry result in to cost effective construction and promotes the use of materials having less embodied energy. Use of precast walling units and roofing units also promotes the use of materials having less embodied and functional energy.

\subsection{Recycling of building wastes}

Many utilised building materials can be recycled for construction [6]. They include

- Processed aggregated obtained from demolished buildings.

- Steel from demolished RCC buildings be used for non structural purpose and the steel can also be recycled for reuse.

- Filled earth in basement of demolished buildings can also be reused.

- Brick can be used as a whole or as crushed brick aggregates.

- Other suitable building materials such as wood, plastics, and tiles, electric wires can also be used, based on their suitability for reuse.

\subsection{Use of renewable energy sources}

Renewable energy sources are solar energy, wind energy, tidal energy etc, But for buildings, the use of solar energy is direct and portable. Solar energy can be harnessed in two ways in a building. One is for electricity production and another is for heat production. Electricity can be produced from Photo voltaic (PV) cells and the heat from solar water heaters. Installation of PV cells results in to substantial savings in energy cost of a building in the long run. Even though the initial cost of installation is higher, Indian central government and the state governments are offering subsidies for installation of PV system and solar water heaters. The solar energy in India is a reliable source of energy as the sunlight is available for most part of the year in over majority regions of India [7]. Installation of Solar water heater saves lot of energy when compared to electrically operated water heaters, which are highly energy intensive.

Biomass energy is another renewable source of energy produced from industrial wastes, municipal wastes and domestic wastes [8]. Various technologies are available for the production of energy from biomass, for adoption in the buildings. Principal production of energy is through incineration and biological processes like anaerobic digestion. For the domestic households, energy can be produced from anaerobic digestion of human wastes and the kitchen solid waste. The wastes could also be converted in to a manure by means of biological decompost techniques and the other liquid wastes from kitchen, bathroom could be filtered by using natural filtering technologies like soak pit and the recycled water could be used for secondary purpose like washing, cleaning and watering the garden etc.,

\subsection{Adoption of energy efficient building techniques}

The process of energy sustainability results from the following [9]

- Choosing appropriate orientations and plans for buildings

- Choosing appropriate building technologies like passive heating and cooling etc.,

- Vegetation planned in the building surroundings

- Use of energy efficient appliances and technologies in buildings

- Adoption of Vernacular construction techniques

Choosing an appropriate orientation while finalising a plan for a building, positioning of openings, providing required area for openings such as doors, windows and ventilators with respect to the climate of the locality, providing shading devices at necessary locations, colour of the external walls, glazing etc., will also help to reduce the energy requirement of a building and thus achieving energy sustainability.

Many building technologies like passive heating and passive cooling have also evolved to achieve energy sustainability. The use of rap trap bond for construction of walls, the use of filler slab for roof construction and others as shown in Table 2 are also results in to sustainable building practices besides being cost effective. 
Choosing appropriate vegetations in and around building premises will also help to achieve energy efficiency in a building, thus achieving sustainability.

Use of energy efficient appliances will help to improve energy efficiency in a building. Use of smart lighting systems, Light Emitting Diode (LED) lights in place of Fluorescent Lamps (FL) and the use of high energy efficiency rated electrical equipments will be of immense use in achieving sustainable energy in a building.

Vernacular architecture plans a building for local environment using locally available materials. The vernacular architecture integrates a building in to the local environment. Sustainability and vernacular construction are synonymous. Hence the practice of vernacular construction shall be encouraged wherever suitable.

\section{Conclusion}

The above essentials form the basis for sustainable building construction practices for Indian construction industry. The sustainable construction must be made the way of construction and the laws shall be enacted to make compulsory the sustainability in construction. Sustainable construction shall also be encouraged by the way of giving subsidies. Vernacular construction which forms the basis of sustainable construction shall also be practised by engineers and architects. The above essential techniques, though are recommended keeping in mind the Indian construction industry, but could also be adopted globally wherever possible.

\section{Acknowledgements}

The author wishes to acknowledge "The Energy and Research Institute (TERI)" whose study and recommendations form the basis of this paper.

\section{References}

1. Sustainable building design manual, Volume 2(2004).The Energy Resource Institute, New Delhi, India

2. Capacity building Series (2009). TARA Nirman Kendra, New Delhi

3. Cork Institute of America- The Natural Choice, https://www.corkinstitute.com/natural.html (Date of consult: 03.11.18

4. A guide to good thatching practice (1998). The division of building and construction technology, Council of Scientific and Industrial Research (CSIR), Pretoria ,South Africa

5. Thatch roofing - Designing 2018,https://www.designingbuildings.co.uk/wiki/Thatch_roofing (Date of consult: 03.11.18)

6. Venkatarama Reddy, B. V. (2004),Sustainable building technologies, Current science, volume 87, no. 7, $899-907$

7. Dr.Tyagi, A. Solar radiant energy over India, (2009). Government of India, Indian Meteorological Department, Ministry of new \& renewable energy, New Delhi, India

8. Dr.Mondal, P. Waste to energy conversion, NPTELonline certification course (2018). Department of chemical Engineering, Indian Institute of Technology (IIT), Roorkee, India

9. Nayak, J.K. and Prajapati, J.A. (2006).Handbook on energy conscious buildings, Ministry of Nonconventional Energy Sources, Government of India. 